\title{
Rio Grande and Rio Conchos water supply variability over the past 500 years
}

\author{
Connie A. Woodhouse ${ }^{1, *}$, David W. Stahle ${ }^{2}$, José Villanueva Díaz ${ }^{3}$ \\ ${ }^{1}$ School of Geography and Development and Laboratory of Tree-Ring Research, University of Arizona, Tucson, Arizona 85721, USA \\ ${ }^{2}$ Department of Geosciences, University of Arkansas, Fayetteville, Arkansas 72701, USA \\ ${ }^{3}$ Instituto Nacional de Investigaciones Forestales, Agricolas y Pecuarias, Gómez Palacio, Durango, Mexico
}

\begin{abstract}
The Rio Grande is a major source of water for parts of Mexico and the USA. The 2 main source regions for the Rio Grande system are the San Juan Mountains of the southern Rocky Mountains and the Sierra Madre Occidental in Mexico, which is the headwaters for the Rio Conchos, the largest tributary of the Rio Grande. Precipitation and streamflow from these 2 source regions are largely independent of each other; winter snowpack is the dominant contributor to the annual streamflow north of the USA-Mexico border, and the North American monsoon is a key factor in the Rio Conchos basin. Reconstructions of water year (October-September) streamflow for a gauge in the upper Rio Grande, 1508-2002, and of October-July precipitation in the Rio Conchos watershed region, 1649-1993, also indicate a lack of correlation between the 2 basins over century time scales. Despite this lack of correlation, periods of concurrent multiyear drought have occurred over the past 4 centuries, most notably in the 1770s, 1890s and 1950s. These rare concurrent droughts in the upper Rio Grande and Rio Conchos source regions may arise from large-scale forcing out of the Pacific Ocean and will be relevant to the binational planning of these water resources, which serve a large and growing population of users.
\end{abstract}

KEY WORDS: Rio Grande - Rio Conchos · Water resources · Dendrochronology · Paleoclimate

\section{INTRODUCTION}

The Rio Grande (Rio Bravo in Mexico) is one of 2 rivers shared by Mexico and the USA. It is a critical source of water for both countries, supplying water to 5 million people, 4 million of whom live along the USA-Mexico border. The Rio Grande is the fifth longest river in North America $(2830 \mathrm{~km})$ and has a drainage basin encompassing $870000 \mathrm{~km}^{2}$; slightly more than half of this area contributes to flow (Dahm et al. 2005). The Rio Grande is considered one of the most impacted rivers in the world and has multiple issues that are related to water quality and quantity (Dahm et al. 2005).

The headwaters of the Rio Grande lie in the San Juan Mountains of Colorado and the runoff is largely from snowmelt. Peak flows for the portion of the river dominated by snowmelt occur from April to June.
The average Rio Grande flow in northern New Mexico is about $43 \mathrm{~m}^{3} \mathrm{~s}^{-1}$. Flows become very limited downstream from the border at El Paso, Texas, and Ciudad Juárez, Mexico. From here, the Rio Grande flow consists mostly of wastewater and irrigation return flows until its confluence with the Rio Conchos (Everitt 1993, Miyamoto et al. 1995, Schmandt et al. 2000). After this point, the main contribution to the Rio Grande comes from the Rio Conchos, which has its headwaters in the Sierra Madre Occidental, a mountain range in northeastern Mexico (Fig. 1). Above the confluence with the Rio Conchos, the Rio Grande average annual flow is about $3 \mathrm{~m}^{3} \mathrm{~s}^{-1}$, while below this confluence the flow averages about $30 \mathrm{~m}^{3} \mathrm{~s}^{-1}$ (Dahm et al. 2005).

Unlike the upper part of the Rio Grande, the Rio Conchos watershed is strongly under the influence of the North American monsoon. Over $50 \%$ of 


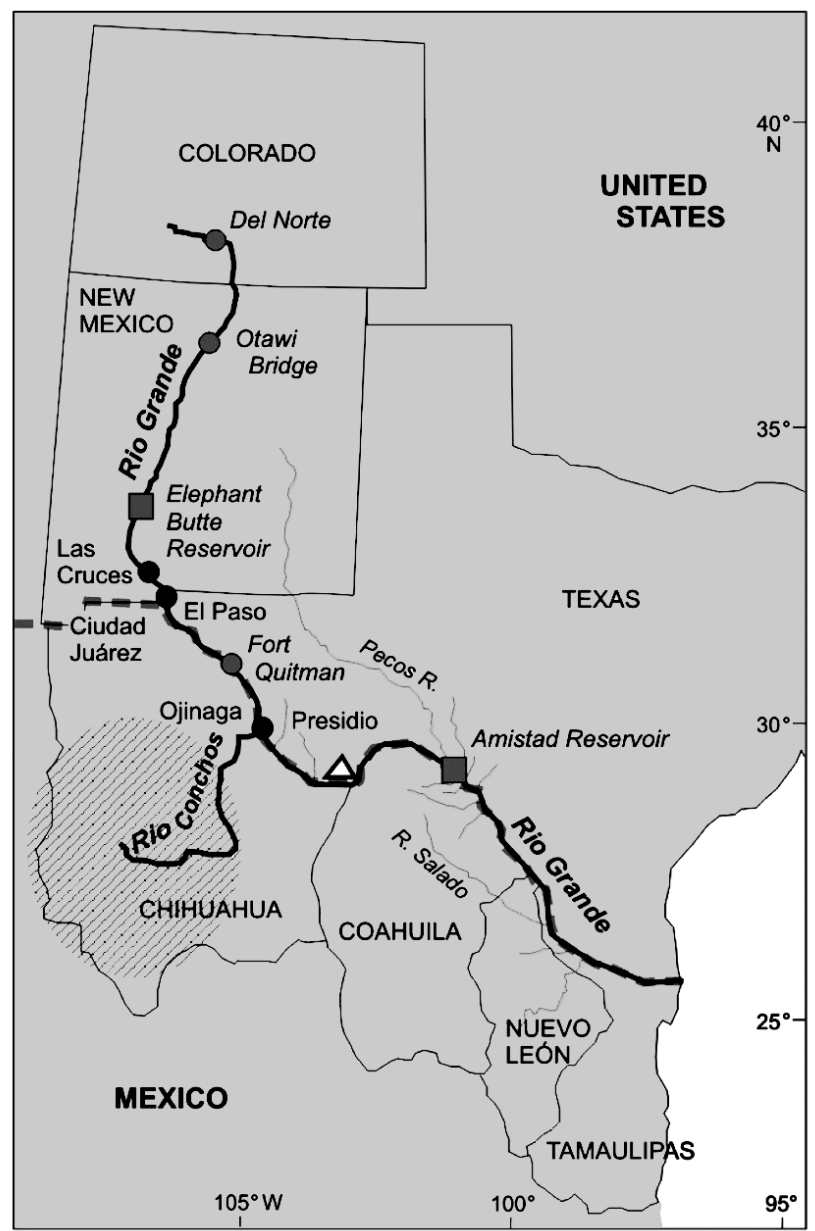

Fig. 1. The Rio Grande and Rio Conchos in southern USA and Mexico. The Rio Grande near Del Norte, Colorado, is indicated as is the Rio Conchos, the coverage of Mexico Climate Division 5 (hatching) and other points mentioned in the text (cities are black dots, gauge location are grey dots, reservoirs are grey squares and Big Bend National Park is marked with a white triangle). The USA-Mexico border is indicated by a light broken line. Lower Rio Grande tributaries that are part of the 1944 international treaty are shown in light gray lines

the annual precipitation in this region is delivered through the monsoon between mid-June and midSeptember (Dahm et al. 2005), although some summer precipitation is due to tropical storms in certain years. In winter, westerly storms bring additional precipitation, but cool season (November-May) flows make up just $10 \%$ of the total annual flow. Research in the adjacent Rio Yaqui basin indicates that although cool season precipitation represents a smaller proportion of the annual precipitation, it is highly correlated with winter streamflows, which, in turn, are highly correlated with annual reservoir inflows (Nicholas \& Battisti 2008), and this is probably the case in the Rio Conchos as well. Winter flows are important for replenishment of reservoirs and have greater efficiency than summer runoff because of lower evaporation rates during the cool season. The Rio Conchos drainage area accounts for about $14 \%$ of the total drainage area of the Rio Grande, but its flow accounts for a much greater proportion of the total flow because of upstream depletions in the Rio Grande. The Rio Conchos is the source for much of the flow through Big Bend National Park, Texas, and its flows are a primary source of water for the Amistad International Reservoir, the main reservoir in the lower Rio Grande basin (IBWC 2009) (Fig. 1).

The Rio Grande is a critical water supply for the region through which it passes. Irrigated agriculture production below New Mexico's Elephant Butte Reservoir, the largest reservoir on the upper Rio Grande (Fig. 1), accounts for $80 \%$ of the water withdrawals and is a large contributor to local economies (e.g. over US\$7 billion to the county of El Paso, Texas, in 2003; Michaelsen 2004). The river also provides water for the Middle Rio Grande Conservancy District, 6 northern New Mexico pueblos and instream flows for the endangered Rio Grande silvery minnow Hybognathus amarus (US Bureau of Reclamation 2003).

The region known as Paso del Norte, from Elephant Butte Reservoir to Presidio/Ojinaga, is experiencing population growth, resulting in expanded water demands for municipal and industrial uses in cities that include Las Cruces and El Paso in the USA and Ciudad Juárez and Chihuahua in Mexico. Populations for this region are projected to exceed 4 million by 2020, from just over 2 million in 2000 (PDNWTF 2001). Municipal and industrial water use is projected to increase by $76 \%$ between 2000 and 2020 (PDNWTF 2001). Below Presidio/Ojiaga, the Rio Conchos and its tributaries support agricultural production, with $93 \%$ of the flow being used for irrigated agriculture (Dahm et al. 2005).

\section{ADMINISTRATION AND MANAGEMENT}

The Rio Grande is a complex river system distinguished by a legacy of international treaties and multiple administrative agencies. Three main treaties allocate Rio Grande water resources: 2 international treaties, in 1906 and 1944, and 1 interstate treaty, in 1938. The 1906 international treaty between the USA and Mexico allocated 78 million $\mathrm{m}^{3}$ of Rio Grande flow annually to Mexico at Ciudad Juarez (Thomas et al. 1963). The Rio Grande Interstate Compact was negotiated in 1938 between Colorado, 
New Mexico and Texas. It allocated upper Rio Grande flow, as measured near the Colorado-New Mexico state line, for deliveries to New Mexico and at Otowi Bridge in New Mexico for deliveries to Elephant Butte Reservoir for allocation to Texas (Thomas et al. 1963) (Fig. 1). The 1944 international treaty addressed Rio Grande flow in the lower basin between Fort Quitman, Texas, and the Gulf of Mexico. In this treaty, Mexico's allotment includes two-thirds of the flow from the Rio Conchos and 5 smaller Mexican tributaries (Rios San Diego, San Rodrigo, Escondido, Salado, Arroyo de las Vacas), all the water from the San Juan and Alamo rivers and $50 \%$ of the flows from unmeasured tributaries. The USA is to receive one-third of the flow from the Rio Conchos and the 5 Mexican tributaries, all the flows from US tributaries (Pecos and Devils rivers, Goodenough Spring and Alamito, Terlingua, San Felipe and Pinto creeks) and $50 \%$ of unmeasured tributaries. The US allocation is no less than an annual average of 431.7 million $\mathrm{m}^{3}$ in $5 \mathrm{yr}$ cycles (i.e. over a 5 yr period) from the Rio Conchos and the other Mexican tributaries (Spener 2007).

Drought and growing water demands have resulted in water conflicts in recent years (Kelly 2002). Historically, unregulated runoff was sufficient to fulfill Mexico's treaty obligations to the USA (Spener 2007). But droughts, coupled with increased irrigation in Mexico, led to delivery deficits in the mid to late 1990s and early 2000s. While Mexico claimed extraordinary drought as the reason for the deficits, extraordinary drought is not defined in the 1944 treaty, and conflict persisted until the obligation was paid off in 2005 when reservoirs refilled due to high precipitation (Dahm et al. 2005). The conflict brought to the forefront the issue of drought extremes and whether allowances due to drought should be made for Mexico's delivery obligations.

In some respects, the portion of the Rio Grande that is supplied by the San Juan Mountain headwaters and the Rio Conchos may be considered to be 2 different rivers. The source regions, climatic controls and administration for each, while not mutually exclusive, are largely distinct, and the upper and lower parts of the river are legally managed as 2 different systems (A. Michaelsen pers. comm.). However, management must consider the entire river, and the relationship between these 2 parts is key to the administration of the river in a way that meets the needs of all users.

In this study, we examined the 2 source regions of the Rio Grande system, the Rio Grande and Rio Conchos headwaters, to determine the range of hydro- climatic variability that has occurred, and the nature and degree of coherence of drought in these 2 areas over the past 4 centuries. To gain this long-term perspective, we generated and compared tree-ring based reconstructions of water year (October-September) streamflow for the Rio Grande headwaters and October-July total precipitation in the Rio Conchos watershed. Although Rio Conchos precipitation for October-July does not reflect a large part of the monsoon precipitation or the occasional early fall tropical storm, constraints of the tree-ring data currently available prevent high quality reconstructions of total monsoon precipitation in this region. However, the October-July total correlates well with water year precipitation and may be considered a proxy for water year precipitation. Thus, it can provide some insights into the relationship between the hydroclimatology of the 2 regions. Although treering based reconstructions of the summer Palmer Drought Severity Index (PDSI) exist for both regions (Cook et al. 2007), here we were interested in the temporal and spatial variability of water supply, rather than drought per se, although we did consider the spatial pattern of drought from PSDI as part of the analysis.

\section{INSTRUMENTAL DATA}

The common time period for the instrumental records for the Rio Grande and Rio Conchos watersheds spanned the years 1922-2006. We used the gauge at Del Norte, Colorado, to represent headwaters flow because of the long and relatively undepleted flow record available (i.e. few or no diversions of flow have been made for irrigation or other uses upstream from this gauge). Annual flows, measured as the water year from October to September, were obtained from the Rio Grande (Colorado) Water Conservation District. The Rio Conchos lacks long, natural flow records. Although less than ideal for comparison with the Rio Grande flow, monthly divisional precipitation data were used, obtained from A. V. Douglas (pers. comm.). We used Mexican Climate Division 5 because it closely coincides with the upper Rio Conchos watershed (Fig. 1). Water year precipitation was used for the comparison with Rio Grande water year streamflow. Mexican Division 5 OctoberJuly precipitation was also analyzed, as this was the period used in the Rio Conchos reconstruction. October-July total precipitation represented $58 \%$ of the annual precipitation and was correlated with water year precipitation $(\mathrm{r}=0.865, \mathrm{p}<0.01)$. 
Water year precipitation in the Rio Conchos watershed and water year streamflow in the Rio Grande headwaters were not significantly correlated $(\mathrm{r}=0.080$, $\mathrm{p}=0.496$; Rio Conchos October-July precipitation and water year Rio Grande streamflow were also not significantly correlated $r=0.111, p=0.313$ ). For comparison, upper Rio Grande basin water year precipitation (gridded data from parameter-elevation regressions on independent slopes model [PRISM]; Daly et al. 2002) was significantly, although not highly correlated with Rio Conchos water year precipitation $(\mathrm{r}=0.305, \mathrm{p}=0.005$, $\mathrm{n}=85)$ as well as with Rio Conchos October-July precipitation $(\mathrm{r}=0.298, \mathrm{p}=$ $0.006, \mathrm{n}=85$ ). A period of below average flows in the Rio Grande in the 1960s was one of above average precipitation in the Rio Conchos, and 1981, which was one of the driest winters throughout Colorado, was one of the 5 wettest years in the Rio Conchos. Conversely, the 1920s were mostly dry in the Rio Conchos, while this was a period of wet conditions in the Rio Grande headwaters (Fig. 2). Some droughts were shared and drought years during the 1950s (1951, 1953 and 1956) fell into the driest 25th percentile of both records, as did the individual drought years of 1934 and 1974 (for the October-July total as well).

The 2 time series, for Rio Grande streamflow and Rio Conchos precipitation, graphed as 5 yr moving averages showed some periods of coherence, most notably in the 1930s and 1950s, which were periods of widespread drought across large areas of North America. Although the 1930s drought was not as severe in the southwestern USA compared with that in the Great Plains (Fye et al. 2003), it does appear to have been a more persistent period of below average precipitation in the Rio Conchos basin (Fig. 2). The heart of the 1950s drought was in the southwestern USA and northern Mexico (Fye et al. 2003, Stahle et al. 2009), and its severity is evident in both records. The drought of record (in terms of cumulative deficits over runs of below average years) in the Rio Grande headwaters was the most recent drought, which appeared to be less severe in the Rio Conchos water year precipitation, and in the October-July precipitation did not appear as a period of drought at all (Fig. 2, lower panel), although it was a period of anomalously warm temperatures (Stahle et al. 2009).
In summary, the instrumental records suggest that although the hydroclimatic variability in the 2 watersheds is not closely coupled, there were some periods (the 1950s in particular) when drought occurred in both watersheds, which could be due to chance and/or to a large-scale circulation feature.

\section{HYDROCLIMATIC RECONSTRUCTIONS}

\subsection{Rio Grande headwaters}

Moisture-sensitive tree-ring species (Pinus ponderosa, Pinus edulis and Pseudotsuga menzeisii) in Colorado and other parts of the western USA are well correlated with streamflow because both annual tree growth and water year flows reflect the cumulative effects of precipitation (particularly snowfall) and evapotranspiration over the course of the water year (Meko et al. 1995, Woodhouse et al. 2006). A number of tree-ring chronologies from these species are available for the upper Rio Grande watershed and neighboring watersheds with similar climate (i.e. the southern portion of the Colorado River basin and the Arkansas River basin) (International Tree-Ring Data Bank; Woodhouse et al. 2006). For the reconstruction 
of the Rio Grande near Del Norte, these chronologies were screened by using a 2-step process: (1) chronologies were screened to include the common time period, 1508-2002; (2) these chronologies were further screened, retaining those that were significantly correlated $(\mathrm{p}<0.01)$ with the Rio Grande gauge record, for the period common to both tree-ring chronologies and gauge data, 1890-2002, and for this period split into halves. A total of 15 chronologies passed both levels of screening and were candidate predictors for the reconstruction model. Residual chronologies (with persistence considered to be biological in origin removed; Fritts 1976) were used because the gauge record contained no significant loworder autocorrelation.

To develop a reconstruction model, the tree-ring chronologies were calibrated with the gauge record over the full common period (1890-2002) by means of a forward stepwise regression. A model resulted in which 4 predictors explained $71 \%$ of the total variance (Tables 1 \& 2A, Fig. 3a). This model met regression assumptions, including a lack of significant autocorrelation (as indicated by the Durban-Watson $D$ and Lag 1 autocorrelation; Table 2B), although residuals had a slight nonsignificant negative trend. A leave-one-out cross validation process (Michaelsen 1987) confirmed the skill of the reconstruction model (Table 3). Validation statistics, the reduction of error (RE) (Fritts et al. 1990) and root mean square error (RMSE) (Weisberg 1985), were generated to assess the skill of the model with estimates from the leave-one-out process (Table 3). The $\mathrm{RE}$ tests the skill of the model compared with estimates based on the mean of the validation data. The RMSE for the validation data is comparable with the standard error (SE) of the estimate for the calibration data. Both are used to assess possible model overfit. For further validation of the skill of this set of predictor chronologies, separate stepwise regression models were run on the early and late halves of the common time period, resulting in almost identical sets of predictors being selected, and on models that validated well on the withheld parts of the data (Table 3). The full Rio Grande flow reconstruction generated from this model covers the years from 1508 to 2002 .

The Rio Grande reconstruction indicates periods of more severe and persistent low flow than any recorded in the gauge record. One of longest runs of

Table 1. Chronologies used in reconstruction models. All chronologies are available through the International Tree-Ring Data Bank (www.ncdc.noaa.gov/paleo/treering. html). pied: Pinus edulis; psme: Pseudotsuga menzeisii

\begin{tabular}{|c|c|c|c|c|c|}
\hline Name & Code & Species & Years & Location & Source \\
\hline \multicolumn{6}{|l|}{ Rio Grande } \\
\hline Slickrock & SLK & pied & 1490-2002 & Colorado & Woodhouse et al. 2006 \\
\hline Trail Gulch & TRG & pied & $1402-2002$ & Colorado & Woodhouse et al. 2006 \\
\hline Natural Arch & ARC & pied & $1508-2002$ & Colorado & Present study \\
\hline Cathedral Creek & CAT & psme & 1366-2002 & Colorado & Woodhouse et al. 2006 \\
\hline \multicolumn{6}{|l|}{ Rio Conchos } \\
\hline \multicolumn{6}{|l|}{ Earlywood } \\
\hline Cerro Baraja & $\mathrm{CBA}$ & psme & $1439-2006$ & Durango & $\begin{array}{l}\text { Stahle et al. 2000b } \\
\text { (Villanueva update) }\end{array}$ \\
\hline Creel & CIA & psme & $1645-1993$ & Chihuahua & Stahle et al. $2000 \mathrm{~b}$ \\
\hline \multicolumn{6}{|l|}{ Latewood } \\
\hline El Tabacote & TAB & psme & $1622-1993$ & Chihuahua & Stahle et al. 2000b \\
\hline Creel & CIA & psme & 1649-1993 & Chihuahua & Stahle et al. 2000b \\
\hline Las Tinejas & TIN & psme & $1624-1993$ & Chihuahua & Stahle et al. 2000b \\
\hline Cerro Baraja & CBA & psme & $1440-2006$ & Durango & $\begin{array}{l}\text { Stahle et al. 2000b } \\
\text { (Villanueva update) }\end{array}$ \\
\hline
\end{tabular}

Table 2. Regression statistics. (A) Statistics for the 2 reconstruction models. (B) Regression model results. Rio Grande reconstruction model based on 1890-2002; Rio Conchos reconstruction model based on 1940-1977

\begin{tabular}{|c|c|c|c|c|c|c|}
\hline \multicolumn{2}{|c|}{ A Regression terms } & \multicolumn{3}{|c|}{$b$ coefficient } & $t$ & $\mathrm{p}$ \\
\hline \multicolumn{7}{|l|}{ Rio Grande } \\
\hline \multicolumn{2}{|l|}{ Intercept } & \multicolumn{3}{|c|}{-3081.5} & -0.073 & 0.942 \\
\hline \multicolumn{2}{|l|}{ Slickrock } & \multicolumn{3}{|c|}{230233} & 5.432 & $<0.001$ \\
\hline \multicolumn{2}{|l|}{ Trail Gulch } & \multicolumn{3}{|c|}{191766} & 5.096 & $<0.001$ \\
\hline \multicolumn{2}{|l|}{ Natural Arch } & \multicolumn{3}{|c|}{151537} & 3.512 & $<0.001$ \\
\hline \multicolumn{2}{|c|}{ Cathedral Creek } & \multicolumn{3}{|c|}{79066.1} & 2.224 & 0.028 \\
\hline \multicolumn{7}{|c|}{ Rio Conchos } \\
\hline \multicolumn{2}{|l|}{ Intercept } & \multicolumn{3}{|c|}{69.4} & 1.498 & 0.144 \\
\hline \multicolumn{2}{|c|}{ Earlywood average } & \multicolumn{3}{|c|}{229.9} & 4.971 & $<0.001$ \\
\hline \multicolumn{2}{|c|}{ Latewood average } & \multicolumn{3}{|c|}{202} & 2.807 & 0.008 \\
\hline $\begin{array}{l}\text { B Regression } \\
\text { model results }\end{array}$ & $\begin{array}{l}\text { No. of } \\
\text { cases }\end{array}$ & $\mathrm{R}^{2}$ & $F$ & $\mathrm{p}$ & $\begin{array}{l}\text { Durban- } \\
\text { Watson } D\end{array}$ & $\begin{array}{l}\text { Lag } 1 \text { auto- } \\
\text { correlation (r) }\end{array}$ \\
\hline Rio Grande & 113 & 0.713 & 67.242 & $<0.001$ & $1.727^{\mathrm{a}}$ & $0.131^{\mathrm{b}}$ \\
\hline Rio Conchos & 35 & 0.532 & 18.210 & $<0.001$ & $1.900^{\mathrm{a}}$ & $0.037^{\mathrm{b}}$ \\
\hline \multicolumn{7}{|c|}{$\begin{array}{l}{ }^{a} \text { Null hypothesis of zero first order autocorrelation cannot be rejected at the } 0.01 \\
\alpha \text {-level } \\
{ }^{b} \text { Not significantly different }(p>0.05 \text { ) from zero, based on Ljung-Box } Q \text { test }\end{array}$} \\
\hline
\end{tabular}


below average flows was 7 yr in 1579-1585. This period coincides with drought conditions that have been documented throughout western North American (e.g. Stahle et al. 2000a). However, the most persistent drought in this record occurred 1873-1883 (Fig. 4a). Flows over this 11 yr period averaged $74 \%$ of the long-term average. The most severe drought (in terms of annual deficit) was a 5 yr run, 1622-1626, during which flows averaged $63 \%$ of the long-term average. This period followed one of the longest runs of above average flows, second only to the wet period of the early 20th century (Fye et al. 2003, Woodhouse et al. 2005) (Fig. 4a).

\subsection{Rio Conchos basin precipitation}

The relationships between tree growth and precipitation in the Rio Conchos basin are less straightforward than those in the Rio Grande headwaters because of the monsoon precipitation season. Although annual tree-ring widths tend to correspond to cool season precipitation, measurements of subannual increments of the ring, formed during early and late parts of the growing season (called the earlywood and latewood, respectively), can provide information about both cool season and summer moisture. A number of chronologies for Mexico have been gener-
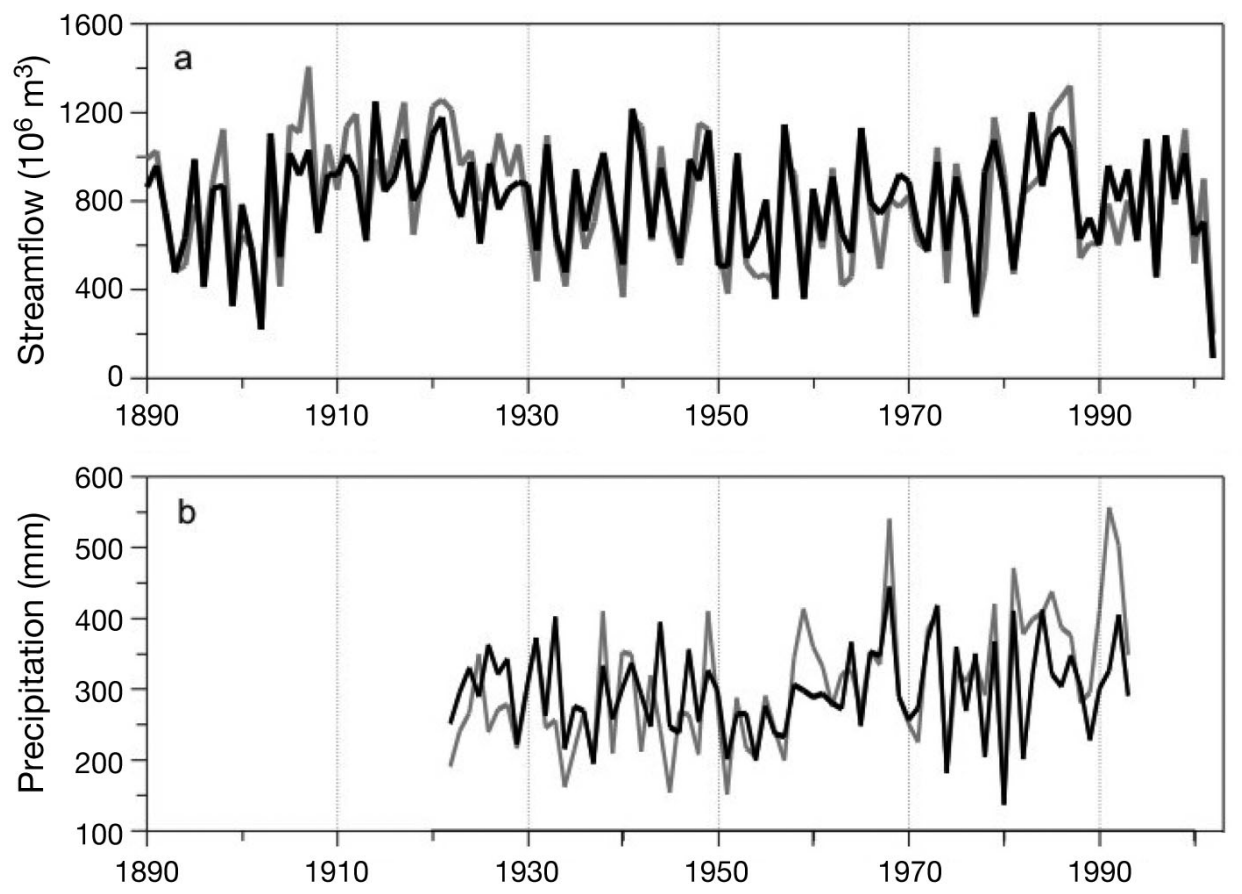

Fig. 3. (a) Observed (light line) and reconstructed (dark line) water year streamflow, Rio Grande near Del Norte, Colorado (1890-2002). (b) Observed (light line) and reconstructed (dark line) OctoberJuly Rio Conchos watershed precipitation (1922-1993)

a

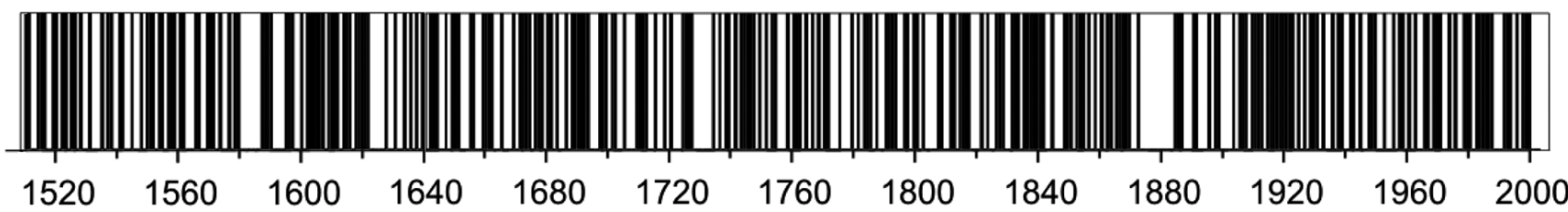

b

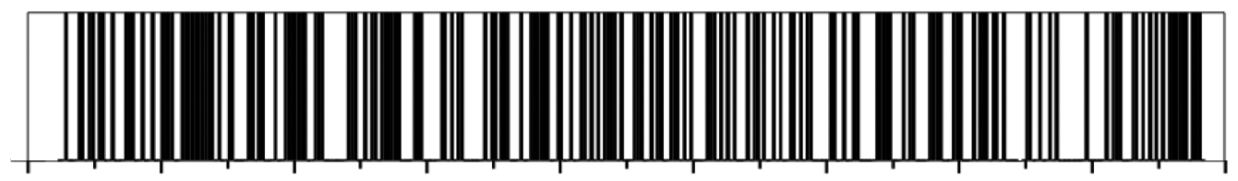

$\begin{array}{llllllllll}1640 & 1680 & 1720 & 1760 & 1800 & 1840 & 1880 & 1920 & 1960 & 2000\end{array}$

Fig. 4. Reconstructions of streamflow and precipitation. Sequences of wet (black) and dry (white) years, i.e. years above or below the long-term average. (a) Rio Grande streamflow 1508-2002. (b) Rio Conchos watershed October-July precipitation 1649-1993 
Table 3. Rio Grande streamflow reconstruction model calibration and verification statistics. $\mathrm{r}(\mathrm{c})$ and $\mathrm{r}(\mathrm{v})$ are the correlations between observed and estimated values for calibration and verification periods, respectively. RE: reduction error; RMSEv: root mean square error for verification period. Site codes for predictors: see Table 1

\begin{tabular}{|llcccccc|}
\hline Model & Predictors & $\mathrm{r}(\mathrm{c})$ & $\begin{array}{c}\mathrm{R}^{2} \\
\left(\mathrm{R}^{2} \text { adjusted }\right)\end{array}$ & $\begin{array}{c}\mathrm{SE} \\
\text { estimate }\end{array}$ & $\mathrm{r}(\mathrm{v})$ & $\mathrm{RE}$ & $\mathrm{RMSEv}$ \\
\hline Full & SLK,TRG,ARC,CAT & 0.845 & $0.713(0.703)$ & 121640 & & 0.69 & 123784 \\
1st half cal & SLK,TRG,ARC & 0.84 & $0.705(0.688)$ & 121700 & 0.834 & 0.682 & 133811 \\
2nd half cal & SLK,CAT,TRG,ARC & 0.863 & $0.745(0.735)$ & 115807 & 0.823 & 0.653 & 137918 \\
\hline
\end{tabular}

the total precipitation for October-July (Table 1).

The reconstruction model was calibrated on the half of the data centered in the middle of the record (1940-1974) and validated on the first (1922-1939) and last (1975-1993) quarters of the data. This calibration-verification strategy was adopted because

ated that include measurements of earlywood, latewood and full ring-width growth increments. For the Rio Conchos watershed reconstruction, a set of primarily Mexican tree-ring chronologies from moisture sensitive species (Stahle et al. 2000b, Cleaveland et al. 2003, Villanueva-Díaz et al. 2008, 2009) was screened in a 2-step process: (1) identification of tree-ring chronologies with the common years from 1772 to 1993; (2) selection of chronologies that were located in climate divisions with precipitation that was significantly correlated with Division 5 precipitation for one or more months, including parts of northern and eastern Mexico and Texas (Mexican data from A. V. Douglas pers. comm.; Texas data from the NOAA National Climatic Data Center). This initial screening process resulted in a set of chronologies from 13 sites, 11 of which included both earlywood, latewood and full ring chronologies, from Pinus ponderosa, Pseudotsuga menzeisi and Taxodium mucronatum. Further screening identified significant correlations with Division 5 precipitation for the months from October before the growth year to September of the growth year. Full ring and earlywood chronologies correlated with October-May precipitation, while a handful of latewood chronologies correlated with June and July precipitation. We elected to use the earlywood and latewood chronologies because of their complementary seasonal climate signals and the residual form of the chronologies, as we did with the Rio Grande reconstruction. Individual latewood chronologies were regressed on associated earlywood chronologies to remove the dependence of the latewood growth on the earlywood growth (Meko \& Baisan 2001), and the resulting adjusted latewood residual chronologies were used for subsequent analysis.

Based on correlation results that tested different combinations of total monthly precipitation, a set of 2 potential predictors was generated by averaging the 2 earlywood chronologies and the 4 latewood chronologies that were most strongly correlated with the first half of the precipitation time series was dissimilar to the second half with respect to the mean and variance, and it was not possible to calibrate a model on one-half of the data that would perform well on the other half. In addition, the number of climate station records available varies widely through time, with fewer stations at the beginning of the period and a marked loss of stations over the last 3 decades (Zhu \& Lettenmaier 2007), so this middle period is likely to be the best reflection of regional climate. The 2 predictors, the averages of earlywood and latewood chronologies, were used in a stepwise regression to estimate October-July total precipitation for 1940-1974. Both predictors entered, resulting in a regression model that explained $53 \%$ of the total variance and met regression assumptions, although residuals displayed a slight nonsignificant positive trend (Table 2A,B). This model was validated on the data withheld from the calibration, and results indicate modest skill of the reconstruction model on the independent data (Table 4, Fig. 3b). The correlation between observed and estimated values for the full common period, 1922-1993, was $r=0.653(p<0.05)$. A full reconstruction was then generated for the years 1649-1993.

The Rio Conchos precipitation reconstruction was characterized by runs of below average precipitation years (based on the long-term average, 1649-1993) that included periods that lasted 5, 6, 7 and 8 yr. Two of these periods overlapped or fell within periods of persistent drought in the Rio Grande headwaters record. The 7 yr period 1729-1735 overlapped with a 6 yr stretch of low flows in the Rio Grande, but annual precipitation averaged $91 \%$ of the mean, so although persistent, deficits for this period were not extreme. The 5 yr period in the Rio Conchos reconstruction, 1876-1880, fell within the most persistent low flow episode in the Rio Grande reconstruction, although deficits for this set of years were also not as severe in the Rio Conchos precipitation reconstruction (Fig. 4b). The drought with the most extreme 
Table 4. Mexico Climate Division 5 (Rio Conchos watershed) October-July total precipitation reconstruction model calibration and verification statistics. $\mathrm{r}(\mathrm{c})$ and $\mathrm{r}(\mathrm{v})$ are the correlations between observed and estimated values for calibration and verification periods, respectively. RE: reduction error; RMSEv: root mean square error for verification period

\begin{tabular}{|cccccccc}
\hline & Period & $\mathrm{r}(\mathrm{c})$ & $\mathrm{R}^{2}\left(\mathrm{R}^{2}\right.$ adjusted $)$ & SE estimate & $\mathrm{r}(\mathrm{v})$ & $\mathrm{RE}$ & $\mathrm{RMSEv}$ \\
\hline $\begin{array}{l}\text { Calibration } \\
\text { Verification }\end{array}$ & $1940-1974$ & 0.73 & $0.533(0.504)$ & 59 & 0.593 & 0.315 & 79.7 \\
\hline
\end{tabular}

deficits was the period 1890-1894, during which precipitation averaged $70 \%$ of the mean. However, unlike the Rio Grande reconstruction, the run of greatest duration occurred in the 20th century, from 1950 to 1957 (Fig. 4b), in which an average annual precipitation of $82 \%$ of the long-term mean occurred. This period of drought was the most severe drought in Mexico since the drought of the 1560s (Stahle et al. 2009). After a single year of above average precipitation in 1958, this 8-yr period was followed by another prolonged period of below average precipitation, from 1961 to 1963, although this period of drought was much less severe.

\subsection{Comparison of Rio Grande reconstructions}

As in the instrumental records, the reconstructions of Rio Grande headwaters flow and Rio Conchos October-July precipitation were not significantly correlated over the instrumental period (1922-1993: $\mathrm{r}=$ $0.101, p=0.400$ ), but they were significantly although weakly correlated over the full reconstruction period (1649-1993: $\mathrm{r}=0.163, \mathrm{p}=0.002$ ). Also in common with the instrumental records, most of the severe drought years were different between the 2 reconstructed records, but a handful of the very driest (10th percentile) are shared, most of which occurred in the 18 th century $(1748,1763,1773,1798)$. The single year 1934 was the only year in the 20th century that was in the driest 10 th percentile in both records. When smoothed, periods of shared drought became more obvious (Fig. 5). In particular, the periods centered on the 1950s, the late 19th century and 1775 stand out as periods of coherent drought in the 2 regions. Of these periods, the 1950s was the most severe drought period in the Rio Conchos in the past $3 \frac{1}{2}$ centuries, and the peak of this drought occurred simultaneously in both basins. The severity of this drought in the southwestern USA, the southern Great Plains and northern Mexico has been well documented (e.g. Fye et al. 2003, Stahle et al. 2009). The late 19th century contained several periods of sustained drought in the Rio Grande headwaters, including the most sustained period of drought in $500 \mathrm{yr}$, but drought phasing in the 2 basins was not synchronous. This period has been documented in other reconstructions for northern Mexico (Cleaveland et al. 2003), Durango, Mexico (Villanueva-Díaz et al. 2007) and the Nazas basin (Villanueva-Díaz et al. 2005), as well as in regions of the USA, notably the southern Great Plains (Stahle \& Cleaveland 1988, Herweijer et al. 2006). The period of drought centered on 1775 is in phase in both basins, but is less severe in the Rio Conchos, although there is some historical documentation for severe drought during the 1770s in Chihuahua (Endfield \& Fernandez Tejedo 2006).

Spatial patterns for the 3 periods of coinciding drought were assessed by using gridded tree-ring reconstructions of summer PDSI (Cook et al. 2007). Composite maps show the spatial coverage for the most severe droughts in these 2 basins: 1772-1776, 1892-1894 and 1953-1956 (Fig. 6). An additional period of concurrent drought in the late 1660s (16661668 ) is also shown, which indicated widespread, severe drought conditions, although it was less severe

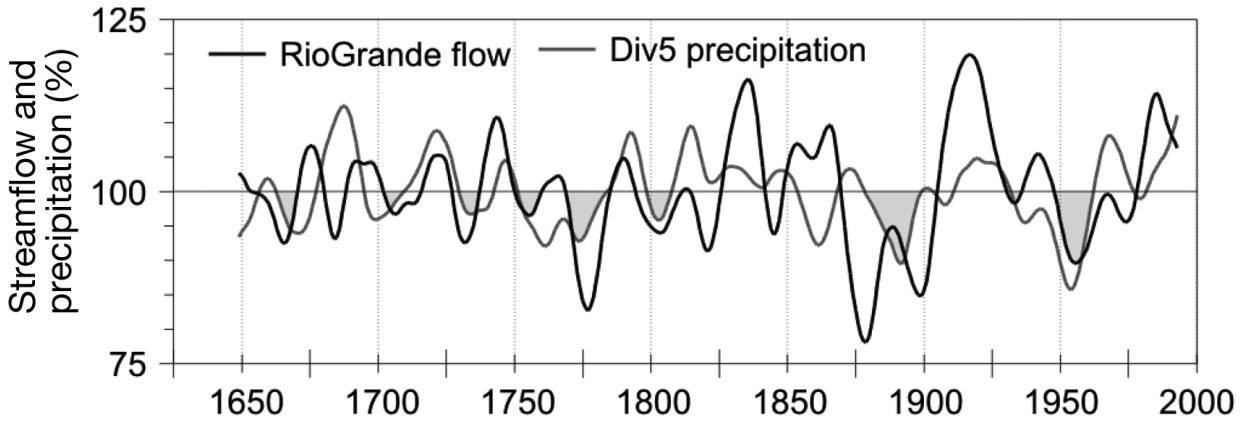

Fig. 5. Reconstructed streamflow for Rio Grande water year flow and Rio Conchos watershed October-July total precipitation, 1649-1993, as percent of average, smoothed with a $20 \mathrm{yr}$ spline. Shading indicates periods when values in both reconstructions are below average 

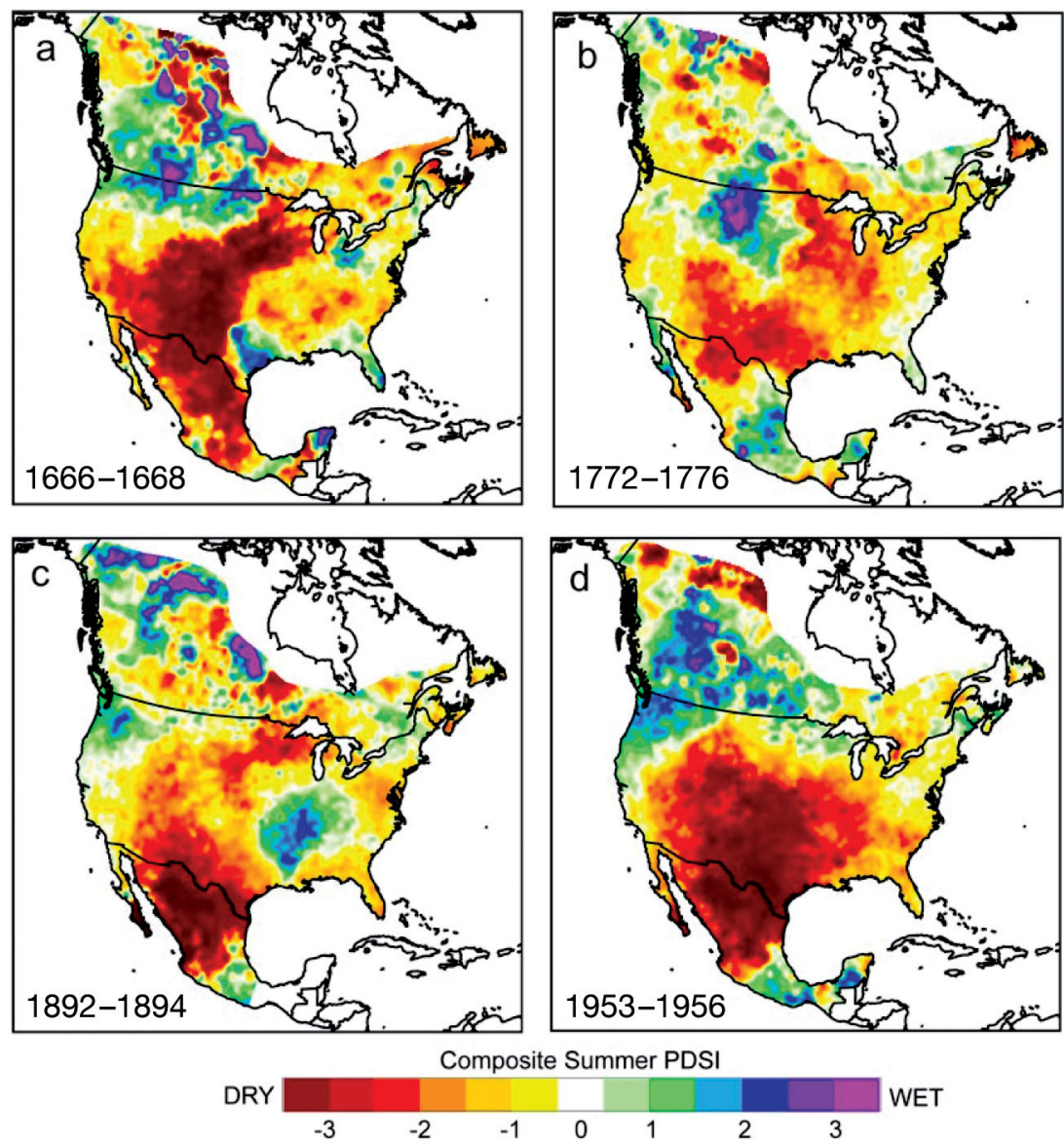

Fig. 6. Palmer Drought Severity Index (PDSI) for periods when both the Rio Grande and Rio Conchos watersheds had concurrent droughts. Data from Cook et al. (2007)

in the 2 basin reconstructions. These are periods of continental-scale droughts that must have had severe effects on water resources as well as on the human and natural systems that relied on these water supplies.

\section{DISCUSSION AND CONCLUSIONS}

The hydroclimatic variability in the headwaters of the Rio Grande and its principal tributary, the Rio Conchos, is not strongly coupled, particularly on a year-to-year basis. This is true for the period of instrumental records, and also appears to be true for the extended reconstruction period, 1649-1993. Reconstructions of Rio Grande streamflow and Rio Conchos watershed precipitation show a great deal of variability over past centuries, and include periods of persistent drought that range from 5 to $8 \mathrm{yr}$. The high degree of temporal variability ensures that droughts occur concurrently in both basins at irregular intervals. Are there common climatic drivers that lead to severe drought in both basins, or do concurrent droughts occur by chance?

A consideration in addressing this question is the seasonality of precipitation, its contribution to streamflow and the moisture delivery mechanisms in both basins. Although the upper Rio Grande basin has a summer precipitation maximum, winter snowpack is the main contribution to annual flows. Winter precipitation is delivered through westerly flow and storms guided by the jet stream. The Rio Conchos watershed is dominated by summer monsoon precipitation and by tropical storms in some years, but cool season precipitation (October-May) makes up about $28 \%$ of the annual total. The Rio Conchos reconstruction presented here, for October-July precipitation, is an expression of both cool season precipitation, a result of the extreme southernmost influence of the jet stream, and the first part of the monsoon season. Thus, the common feature of both basins is the precipitation resulting from the cool season storm track. One control on the position of the storm track that can 
influence both regions is the El Niño/Southern Oscillation (ENSO). The relationship between ENSO events and cool season precipitation in northern Mexico and the southern and southwestern USA has been documented (Ropelewski \& Halpert 1986, 1989, Kiladis \& Diaz 1989); an El Niño event results in a southerly storm track, while during a La Niña event, the storm track moves to the north, leaving the southwestern USA and Mexico dry (e.g. Compo \& Sardeshmukh 2004, Seager et al. 2009). Although the statistical relationship between ENSO and Rio Grande headwaters flow is not significant $(\mathrm{r}=-0.149, \mathrm{p}=0.187$; winter Southern Oscillation Index, 1922-2001, NOAA Climate Prediction Center), low flow years do correspond to some La Niña events (e.g. 1951, 1956, 1974 and 2000, based on an index of sea surface temperature [SST] anomalies in the El Niño 3.4 region, NOAA Climate Prediction Center), which suggests there is a nonlinear relationship in this basin. The correlation between ENSO and cool season (October-May) precipitation for the Rio Conchos watershed is significant ( $\mathrm{r}=-0.437, \mathrm{p}<0.001, \mathrm{n}=80$ ); thus ENSO may at times be a common control on winter precipitation in both regions. Both the 1950s and 1890s droughts occurred during La Niña events (Seager et al. 2009).

However, for severe concurrent droughts in both basins, it is necessary to have both a dry winter, typically a La Niña event, and a weak monsoon. In the North American monsoon region, La Niña and El Niño events tend to correspond with greater and lesser monsoon precipitation, respectively (Higgins et al. 1998, 1999, Castro et al. 2001). This suggests that a dry summer and a dry winter will not occur during the same phase of ENSO, although if a La Niña event changes sign in the late spring to El Niño conditions by summer, then a dry winter could well be followed by a dry summer. The decade of the 1950s contained a number of years with below average observed and reconstructed streamflow or precipitation in both basins (6 of $10 \mathrm{yr}, 1950-1951$ and 1953-1956). This decade was characterized by several strong La Niña events that generally coincided with drought that persisted into the warm season. The 1950s also coincided with the negative phase of the Pacific Decadal Oscillation (PDO; Mantua et al. 1997), which can enhance La Niña effects (Gershunov\& Barnett 1998) and may also influence monsoon variability (Higgins \& Shi 2000, Castro et al. 2001). But the linkage between La Niña conditions and strong monsoons was not evident in the 1950s, and the role that the PDO may have played in the persistence of drought and monsoon precipitation is not clear. Further complicating this interpretation is the fact that October-July precipitation reflects both cool and warm season precipitation influences, but not the full monsoon season. In the 1950s drought years, the proportion of the October-July precipitation accounted for by June and July is just over one-half, which is consistent with the average June-July proportion over the full precipitation record and suggests that June and July were not unusual with respect to their contribution. Since both winter and summer were dry in northern Mexico over much of this period (Stahle et al. 2009), it is likely that other factors in addition to ENSO and Pacific decadal variability, such as Atlantic Ocean conditions, were responsible.

The reconstructed time series show periods when Rio Grande water year streamflow and Rio Conchos October-July precipitation were both in phase and out of phase (Fig. 5), indicating that one or more underlying circulation mechanisms influence both regions. Nicholas \& Battisti (2008) found that cool season precipitation in the Rio Yaqui basin, adjoining the Rio Conchos basin, was strongly influenced by ENSO and highly correlated to annual reservoir inflow, which is in agreement with our results for the Rio Conchos. ENSO is also likely to be an important control on severe drought in the Rio Grande headwaters in at least some years. However, although there is a growing body of research examining the effects of ocean and atmosphere circulation on regional drought at annual and multidecadal timescales (e.g. Gershunov \& Barnett 1998, Castro et al. 2001, Brown \& Comrie 2004, Kiem \& Franks 2004, McCabe et al. 2004, Verdon-Kidd \& Kiem 2010), more research is needed on the relationship between cool and monsoon season precipitation and the circulation mechanisms that control their variability.

Concurrent drought in the Rio Grande headwaters and the Rio Conchos watershed, a component of natural hydroclimatic variability, must be considered in water resouce management, along with a future that includes increasing water demands as well as climate changes that will further stress water supply and increase demand (Seager et al. 2007, Solomon et al. 2007). An acknowledgement that concurrent droughts have occurred in the past, and may occur in the future, will be relevant to the binational water policy discussions that address drought impacts in both basins. Long paleoclimatic records are critical for placing relatively uncommon events, such as concurrent drought across the full Rio Grande basin, in a long-term context and are useful for water resources management in other arid and semi-arid parts of the world (Kiem \& Franks 2004, Verdon-Kidd \& Kiem 2010). 
Acknowledgements. The motivation for this study came from discussions during a USA-Mexico borders workshop convened by G. Garfin of the Institute of the Environment, University of Arizona, and J. Jones of the California Department of Water Resources. We gratefully acknowledge F. Fye for the generation of the PDSI maps and the editorial comments from G. Garfin. Comments from reviewer A. Kiem are also greatly appreciated, as well as those from an anonymous reviewer and the editor.

\section{LITERATURE CITED}

Brown DP, Comrie AC (2004) A winter precipitation 'dipole' in the western United States associated with multidecadal ENSO variability. Geophys Res Lett 31:L09203

> Castro CL, McKee TB, Pielke RA Sr (2001) The relationship of the North American monsoon to tropical and North Pacific sea surface temperatures as revealed by observational analyses. J Clim 14:4449-4473

Cleaveland MK, Stahle DW, Therrell MD, Villanueva-Díaz J, Burns BT (2003) Tree-ring reconstructed precipitation and tropical teleconnections in Durango, Mexico. Clim Change 59:369-388

Compo GP, Sardeshmukh PD (2004) Storm track predictability on seasonal and decadal scales. J Clim 17: 3701-3720

> Cook ER, Seager R, Cane MA, Stahle DW (2007) North American drought: reconstructions, causes, and consequences. Earth Sci Rev 81:93-134

Dahm CN, Edwards RJ, Gelwick FP (2005) Gulf Coast rivers of the southwestern United States. In: Benke A, Cushing C (eds) Rivers of North America. Elsevier, Amsterdam, p 181-228

Daly C, Gibson WP, Taylor GH, Johnson GL, Pasteris P (2002) A knowledge-based approach to the statistical mapping of climate. Clim Res 22:99-113

Endfield GH, Fernandez Tejedo I (2006) Decades of drought, years of hunger: archival investigations of multiple year droughts in late Colonial Chihuahua. Clim Change 75 : 391-419

Everitt B (1993) Channel response to declining flows on the Rio Grande between Fort Quitman and Presidio, Texas. Geomorphology 6:225-242

Fritts HC (1976) Tree rings and climate. Academic Press, London

Fritts HC, Guiot J, Gordon GA (1990) Verification. In: Cook ER, Kairiukstis LA (eds) Methods of dendrochronology, applications in the environmental sciences. Kluwer, Dordrecht, p 178-185

> Fye FK, Stahle DW, Cook ER (2003) Paleoclimatic analogs to twentieth-century moisture regimes across the United States. Bull Am Meteorol Soc 84:901-909

Gershunov A, Barnett TP (1998) Interdecadal modulation of ENSO teleconnections. Bull Am Meteorol Soc 79: 2715-2726

Herweijer C, Seager R, Cook ER (2006) North American drought of the mid to late nineteenth century: history, simulation and implications for medieval drought. Holocene 16:159-171

> Higgins RW, Shi W (2000) Dominant factors responsible for interannual variability of the summer monsoon in the southwestern United States. J Clim 13:759-776

Higgins RW, Mo KC, Yao Y (1998) Interannual variability of the U.S. summer precipitation regime with emphasis on the southwestern monsoon. J Clim 11:2582-2606

> Higgins RW, Chen Y, Douglas AV (1999) Interannual variability of the North American warm season precipitation regime. J Clim 12:653-680

IBWC (International Boundary and Water Commission) (2009) Rio Grande flow/reservoir conditions. www.ibwc. state.gov/Water_Data/Reports/RG_Storage_Conditions. htm\#

Kelly ME (2002) Tratado de aguas bilateral México-U.S.A.: the dispute over shared waters of the Rio Grande/Rio Bravo. Memoria de la XIV Semana Internacional de Agronomía FAZ-UJED, Durango

Kiem AS, Franks SW (2004) Multi-decadal variability of drought risk, eastern Australia. Hydrol Process 18:2039-2050

Kiladis GN, Diaz HF (1989) Global climatic anomalies associated with extremes in the Southern Oscillation. J Clim 2:1069-1090

> Mantua NJ, Hare SR, Zhang Y, Wallace JM, Francis RC (1997) A Pacific interdecadal climate oscillation with impacts on salmon production. Bull Am Meteorol Soc 78:1069-1079

> McCabe GJ, Palecki MA, Betancourt JL (2004) Pacific and Atlantic Ocean influences on multidecadal drought frequency in the United States. Proc Natl Acad Sci USA 101: 4136-4141

Meko DM, Baisan CH (2001) Pilot study of latewood-width of conifers as an indicator of variability of summer rainfall in the North American Monsoon region. Int J Climatol 21:697-708

Meko DM, Stockton CW, Boggess WR (1995) The tree-ring record of severe sustained drought. Water Resour Bull 31:789-801

Michaelsen AM (2004) Water resources in West Texas: hydrologic, management, and jurisdiction overview and issues. Presentation to the Texas Senate Select Committee on Water Policy, February 3, 2004, El Paso

> Michaelsen J (1987) Cross-validation in statistical climate forecast models. J Clim Appl Meteorol 26:1589-1600

Miyamoto S, Fenn LB, Swietlik D (1995) Flow, salts, and trace elements in the Rio Grande: a review. Tech Rep 169. Texas A\&M University System, Texas Agricultural Experiment Station, Texas Water Resources Institute, College Station, TX

Nicholas RE, Battisti DS (2008) Drought recurrent and seasonal rainfall prediction in the Rio Yaqui, Mexico. J Clim 47:991-1005

PDNWTF (Paso del Norte Water Task Force) (2001) Water planning in the Paso del Norte: toward regional coordination. www.sharedwater.org/PDNWTF/Projects/Reports/ water_taskforce_report_rev1.pdf

Ropelewski CF, Halpert MS (1986) North American precipitation and temperature patterns associated with the El Niño-Southern Oscillation (ENSO). Mon Weather Rev 114:2352-2362

> Ropelewski CF, Halpert MS (1989) Precipitation patterns associated with the high index phase of the Southern Oscillation. J Clim 2:268-284

Schmandt J, Aguilar-Barajas I, Mathis M, Armstrong N and others (2000) Water and sustainable development in the binational lower Rio Grande/Rio Bravo basin. Final Report to EPA/NSF Water and Watersheds program (grant no. R 824799-01-0). Houston Advanced Research Center, Center for Global Studies, The Woodlands, TX

Seager R, Ting M, Held I, Kushnir Y and others (2007) Model projections of an imminent transition to a more arid cli- 
mate in southwestern North America. Science 316: 1181-1184

Seager R, Ting M, Davis M, Cane M and others (2009) Mexican drought: an observational modeling and tree ring study of variability and climate change. Atmósfera 22:1-31

Solomon S, Qin D, Manning M, Marquis M, Averyt K, Tignor MMB, Miller HL Jr, Chen Z (eds) (2007) Climate change 2007: the physical science basis. Contribution of Working Group I to the Fourth Assessment Report of the Intergovernmental Panel on Climate Change. Cambridge University Press, Cambridge

Spener S (2007) International aspects of water management in the arid Southwest. Presented at: Liquid Assets: Using Water in the Arid Southwest Conference, November 3, 2007. School of Advance Research and Museum of New Mexico, Santa Fe

Stahle DW, Cleaveland MK (1988) Texas drought history reconstructed and analyzed from 1698 to 1980. J Clim 1: 59-74

Stahle DW, Cook ER, Cleaveland MK, Therrell MD and others (2000a) Tree ring data document 16th century megadrought over North America. Eos Trans Am Geophys Union 81:121

Stahle DW, Villanueva-Díaz J, Cleaveland MK, Therrell MD and others (2000b) Recent tree-ring research in Mexico. In: Riog F (ed) Dendrochronologia en América Latina. Editorial de la Universidad Nacional de Cuyo (EDIUNC), Mendoza

Stahle DW, Cook ER, Villanueva-Díaz J, Fye FK and others (2009) Early 21st-century drought in Mexico. Eos Trans Am Geophys Union 90:89-100

Thomas HE (1963) Effects of drought in the Rio Grande basin. US Geol Surv Profess Pap 372-D. US Government Printing Office, Washington, DC

US Bureau of Reclamation (2003) Middle Rio Grande project. www.usbr.gov/uc/albuq/rm/mrg/fact/mrg_proj.pdf

Editorial responsibility: Filippo Giorgi,

Trieste, Italy
Verdon-Kidd DC, Kiem AS (2010) Quantifying drought risk in a nonstationary climate. J Hydrometeorol 11: 1019-1031

- Villanueva-Díaz J, Luckman BH, Stahle DW, Therrell MD and others (2005) Hydroclimatic variability of the upper Nazas basin: water management implications for the irrigated area of the Comarca Lagunera, Mexico. Dendrochronologia 22:215-223

Villanueva-Díaz J, Stahle DW, Luckman BH, Cerano-Paredes J, Therrell MD, Cleaveland MK, Cornejo-Oviedo E (2007) Winter-spring precipitation reconstructions from tree rings for northeast Mexico. Clim Change 83: $117-131$

Villanueva-Díaz J, Cerano-Paredes J, Stahle DW, EstradaAvalos J, Constante GV (2008) Potencial dendrocronológico de Pseudotsuga menziesii (Mirb.) Franco y reconstrucciones de precipitación y flujo en México. Folleto Científico No. 23. INIFAP CENID-RASPA, Gómez Palacio, Durango

Villanueva-Díaz J, Fulé PZ, Cerano-Paredes J, EstradaAvalos J, Sánchez-Cohen I (2009) Reconstrucción de precipitación con anillos de crecimiento de Pseudotsuga menziesii (Mirb.) Franco para el barlovento de la Sierra Madre Occidental. Ciencia For Méx 34:39-77

Weisberg S (1985) Applied linear regression, 2nd edn. John Wiley, New York, NY

Woodhouse CA, Kunkel KE, Easterling DR, Cook ER (2005) The twentieth-century pluvial in the western United States. Geophys Res Lett 32:L07701. doi:1029/2005GL 022413

Woodhouse CA, Gray ST, Meko DM (2006) Updated streamflow reconstructions for the Upper Colorado River basin. Water Resour Res 42:W05415. doi:10.1029/2005WR 004455

> Zhu C, Lettenmaier DT (2007) Long-term climate and derived surface hydrology and energy flux data for Mexico: 1925-2004. J Clim 20:1936-1946

Submitted: December 30, 2010; Accepted: September 21, 2011 Proofs received from author(s): February 10, 2012 